\title{
The Off-Campus Library Services
}

\section{Conference}

\author{
By Barton M. Lessin \\ Assistant Director for Library Off-Campus \\ and Administrative Services \\ Central Michigan University
}

\section{Educators from four countries address library services in support of non-traditional learning.}

$\mathbf{T}$ he Off-campus Library Services Conference, sponsored by the Central Michigan University Libraries and the Institute for Personal and Career Development, was held at the Reno Hilton Hotel in Reno, Nevada, on October 23-24, 1986, for a group of international educators representing the United States, Canada, England, and Australia. In attendance at this conference, which emphasizes the nature of the adult learner and the library services necessary to support non-traditional learning, were librarians, administrators, and faculty members who are directly involved with the provision of academic programs and services to those pursuing courses away from the traditional college campus.

This meeting was organized to combine the comments of five invited featured speakers and presentations by individual practitioners who had had proposals accepted by the conference planning committee. Christine Crocker, senior librarian for reader services at Deakin University, in Geelong, Victoria, Australia, addressed the first plenary session and supplied an overview of distance education and library service in Australia with her presentation entitled, "Getting it Right Down Under." Providing both historical perspective and visuals to support her presentation, Crocker emphasized the tremendous progress which has been achieved during the last several years, but quickly admitted that there remains much to be achieved in support of the adult learner's need for access to information in Australia. Those in attendance were quick to recognize the similarity of problems faced by academicians in the U.S., Canada, and England in our efforts to assure quality library services to off-campus students and faculty.

Ernest Savoie, director of the Employee Development office at the Ford Motor Company, discussed the major role that Ford in concert with the UAW is playing in the career line education and training of its employees. Ford's partnership with the UAW in affecting innovative educational opportunities and tuition assistance programs for hourly employees is recognized as a revolutionary step in employee education. Ford's commitment to the upgrading of such programs includes education for dislocated workers, vocational training, life education, and basic skills enhancement programs. Savoie's comments gave those in attendance in new perspective on the magnitude and scope of adult educational needs in America.

Robert Trullinger, director of the Institute for Personal and Career Development at Central Michigan University, discussed the worker/student and the increasing impact of broad-based private sector reimbursement programs on the way aca- 
demic institutions offer programs off-campus. He predicted that in the near future the successful institutions will be those that promote lifelong learning and diversify their methods of delivery courses and support services. Trullinger noted that innovative ideas for conducting educational programs were being put forward by workers, unions, and managers who all seem eager to renegotiate some of the policies and procedures to which educators have adhered. As a part of his presentation, Trullinger offered suggestions to librarians for enhancing services to the non-traditional learner and encouraged the conference participants to be aggressive in making every effort to assure first-rate library services for all off-campus credit programs.

Dr. Joyce Scott, executive vice-president and dean of faculty at Wichita State University, constructed an overview of higher education and argued that non-traditional programs are basic to its very survival. Major aspects of this presentation covered: 1) demographics of education, 2) characteristics of students, 3) trends in governance and finance, and 4) condition of the academy. The picture painted by Scott was at the same time bleak and challenging. She noted that it is incumbent on higher education to establish an agenda for change based on the lessons we have learned and emphasizing service, innovation, and cooperation.

William A. Gill Jr., chief of the Education Services Branch of the Department of the Air Force's Education Services Division, assisted the conference participants by putting the growth of adult learning into an historical perspective and provid- ing a demographic background to the discussions. As more than 400,000 students annually participate in education programs offered through the Air Force, Gill is in an excellent position to assess the market and the change which is required to make off-campus education more qualitatively attractive. As an example, Gill cited the uneven academic programs of the 1970s and the Air Force's efforts to carefully weed out programs which did not meet specific Air Force criteria for quality. $\mathrm{He}$ noted that both within and beyond the military the market for non-traditional education is growing and that colleges and universities need to create multifaceted and cooperative plans to serve the new student.

The concurrent paper session covered a wide range of topics, including specific case studies of library support development, perceptions of students in regard to library services off-campus, instructional resources as a support function of the library off-campus, online searching for the offcampus student, and the library as a piece of the off-campus puzzle. Also discussed in these sessions were faculty perspectives, separate library collections for off-campus sites, models for providing library services, interactive communications technology and the off-campus student, and the challenges and rewards for the library of working with part-time faculty.

The proceedings of the Off-campus Library Services Conference are in preparation at this time and will include the comments of the featured speakers in addition to the concurrent session pre-

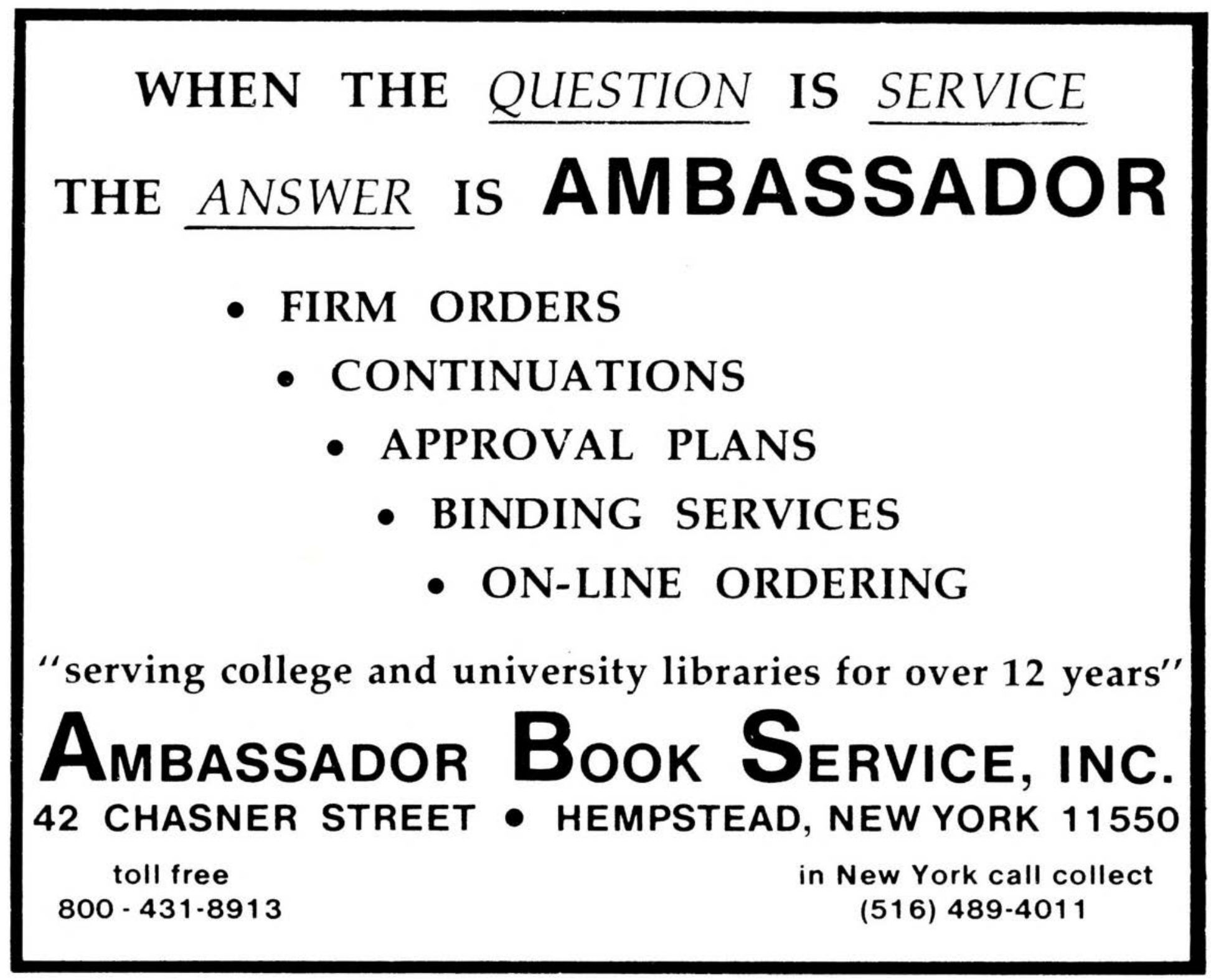


sentations. The cost will be $\$ 15$. Those interested in receiving information about the conference or proceedings are encouraged to contact: Barton $\mathbf{M}$.
Lessin, Central Michigan University, 208 Park Library, Mount Pleasant, MI 48859; (517) 7746419.

\section{C\&RL News guidelines for submission}

\section{of articles or columns}

\section{A statement of purpose and content for College \& Research Libraries News.}

\section{$\mathbf{P}$}

\section{urpose of $C \triangleleft R L$ News}

College \& Research Libraries News is the official news magazine of the Association of College \& Research Libraries, a division of the American Library Association. Its purpose is to record significant activities of ACRL and to report news about academic and research libraries. As the official ACRL news magazine, C $\triangleleft R L$ News maintains a record of selected actions and policy statements of the Association and publishes timely reports on the activities of ACRL and its sections, committees, discussion groups, councils, task forces, and chapters.

As a vehicle for communication among college and research libraries, CひRL News reports news items pertinent to academic and research librarianship, including information on bibliographic instruction, continuing education, appointments, acquisition of special collections, grants to libraries, new technology, and publications (brief notices).

The editor bears responsibility for the contents of each issue of $C \triangleleft R L$ News. Materials selected by the editor must be newsworthy, timely, and of practical value to people in the field. The editor has authority to decide what material is appropriate for publication, based on the following guidelines. The editor also reserves the right to make appropriate revisions in material selected for publication in order to standardize style or improve clarity (ex- cept official ACRL documents, president's letters, and similar material).

Formal, theoretical, or research-oriented articles inappropriate for C $\downarrow R L N e w s$ will be forwarded to the editor of College \& Research Libraries for review.

\section{Length}

Articles and columns should be no more than 3,000 words and no less than 500 words.

\section{Style}

$C \triangleleft R L$ News style is informal, but informative and accurate.

\section{Content}

Materials selected should fall into one of the following categories:

a. Reports on a project, program, or research underway or recently completed dealing with a topic relevant to academic librarianship. Footnotes should be minimal and charts or tables avoided. These reports may be preliminary descriptions of programs or research to be published formally at a later date in library literature (e.g., "Document Delivery Service,” December 1986).

b. Reports on a recent conference or workshop of interest to academic or research librarians (e.g., "The Off-Campus Library Services Conference," January 1987).

c. Reasoned and informed speculation or com- 